\title{
Measuring the influence of customer-based store brand equity in the purchase intention
}

\author{
Medición de la influencia en la intención de compra \\ del valor basado en el consumidor de las marcas del \\ distribuidor
}

\author{
Cristina Calvo-Porral ${ }^{1}$ \\ VAlentín-Alejandro MartíneZ-FernándeZ ${ }^{1}$ \\ Oscar Juanatey-Boga ${ }^{1}$ \\ JEAn-Pierre LÉvy-Mangín ${ }^{2}$ \\ Universidad de La Coruña (España) \\ University of Quebec in Ottawa (Canadá)
}

Recibido el 10 de abril de 2013, aceptado el 11 de julio de 2013

$\mathrm{N}^{\circ}$ de clasificación JEL: M31, M30

DOI: $10.5295 / \mathrm{cdg} .130408 \mathrm{cc}$

\begin{abstract}
:
Store brands account for and important market share in the Spain and a further increase in expected in the next years due to the downturn. However, there is lack of research on store brand customer-based Brand Equity. This study attempts to propose an integrated model of Brand Equity in store or retailer brands, based on Aaker's well-known conceptual model. We propose a consumer-based model, including the main sources or dimensions of Brand Equity and considering the intention to purchase as a consequence. Based on a sample of 362 consumers and 5 store brands, structural equation modeling is used to test research hypotheses. The results obtained reveal that store brand awareness, loyalty along with store brand perceived quality have a significant influence on consumers' intention to purchase store brands. Our study suggests that marketers and marketing managers from retailing companies should carefully consider the Brand Equity components when designing their brand strategies, and develop marketing activities in order to enhance their brands' awareness.
\end{abstract}

Keywords:

Store brand, Brand Equity, purchase intention, retail, structural equation modeling.

\section{Resumen:}

Las marcas del distribuidor suponen una cuota de mercado importante en España y se espera un incremento superior en los próximos años debido a la recesión. Sin embargo, hay una falta de investigación sobre el valor de las marcas del distribuidor basado en el consumidor. Este estudio intenta proponer um modelo integral de

\footnotetext{
${ }^{1}$ Facultad Economía y Empresa, Dpto. Análisis Económico y Administración de Empresas, Campus Elviña s/n, 15071,La Coruña.ccalvo@udc.es; valejand@udc.es; oscarjb@udc.es

${ }^{2}$ Marketing Department, Campus Gatineau, Pavillon Lucient Beault, B2072, Boulevard Alexandre-Taché, 1250, Gatineau (Québec). jean-pierre.levy-mangin@uqo.ca
} 
valor de marca para las marcas del distribuidor o marcas propias, basado en el conocido modelo conceptual de Aaker. Proponemos un modelo basado en el consumidor, que incluye las principales fuentes o dimensiones de valor de marca, considerando la intención de compra como su consecuencia. Basándonos en una muestra de 362 consumidores y 5 marcas del distribuidor, llevamos a cabo um modelo de ecuaciones estructurales para probar las hipótesis de la investigación. Los resultados obtenidos revelan que la notoriedad de las marcas del distribuidor, la lealtad, junto con la calidad percibida, tienen una influencia significativa en la intención de compra de marcas del distribuidor por parte de los consumidores. Nuestro estudio sugiere que los gestores de marketing y comercialización de las empresas de distribución deben considerar cuidadosamente los componentes del valor de marca a la hora de diseñar sus estrategias de marca, y desarrollar atividades de marketing para incrementar la notoriedade de sus marcas.

\section{Palabras clave:}

Marca del distribuidor, valor de marca, intención de compra, distribución, modelo de ecuaciones estructurales. 


\section{INTRODUCTION}

An important and recent trend in the retail industry has been the great growth of store brands, especially among non-durable consumer goods. Spain has become one of the European countries with higher increase in store brands market share (Bigné et al. 2013). More specifically, store brands account for the 35.2 per cent of the market share in the Spanish re- tailing (Private Label Manufacturers Association 2012). Carrying store brands comes with numerous advantages for retailers and leads to a better retailer performance. Store brands represent differentiation tools in retail competition which help engender customer loy- alty, enhance retailer margin and enable retailers to build a high value offering (Corstjens and Lal 2000, Sudhir and Talukdar 2004). Since a large portion of most retailers' revenue and profit comes from selling their own store brands, which many of their competitors also offer, building their own Brand Equity is a particularly challenging problem (Ailwadi and Keller 2004). So, currently retailers have adopted a store Brand Equity enhancement strategy (Pappu and Quester 2006), which enables a successful commercialization of any product category and is a key component of the competitive strategy of retailers. With the prompting trend today toward higher store concentration, the global recession and changing consumer habits, building strong brands has become a marketing priority for many companies nowadays because it provides multiple advantages to establish and create an identity in the market place for a company and it is a key source of competitive advantage (Aaker 1996).

Since the classic researches of Aaker and Keller, Brand Equity has been broadly tested for manufacturer brands (Yoo et al. 2000; Chernatony et al. 2003; Atilgan et al. 2005); whilst there is a lack of research on store brands' equity (De Wulf et al. 2005). Based on previous contributions, we define store Brand Equity on similar elements as any man- ufacturer brand, applying Aaker's (1991, 1996) customer-based Brand Equity model, despite store brands seem to offer a better price-quality relationship than manufacturer brands, since they are targeting and meeting a specific consumers' demand. (Kapferer 2008). Our research goal is to provide a better understanding of the extent to which store Brand Equity contributes to customers' purchase intention, and more specifically the way through which store brands engender value for customers, and consequently influence purchase intent. The present study aims to contribute to the lack of research on this topic, analyzing the influence of the sources of Brand Equity on store brands from the consum- ers' standpoint in a determinate context -the Spanish retailing-, in order to deepen the understanding of the key variables engendering and enhancing store brands' value in the marketplace, giver their increasingly rapid growing market share.

This research seeks to provide a more in-depth understanding of the variables or dimen- sions through which store brands generate value to customers, in order to increase their purchase intention. This paper is structured as follows. In the first section we develop a conceptual framework based on store Brand Equity and its antecedents. This is followed by the description of the methodology adopted. The results are presented and discussed subsequently. Finally, main conclusions and theoretical implications are provided, as well as some suggestions for future research. 


\section{CONCEPTUAL FRAMEWORK}

\subsection{The concept of brand equity and its consequences}

Farquhar (1989) defines Brand Equity as the added value that a brand brings to a particular product or service, and points out that Brand Equity is that set of assets and liabilities linked to a brand, its name or symbol, that incorporate or decrease the value provided by a product or service to the company or its customers. On the other hand, Keller (1993), defines Brand Equity as the marketing effects or outcomes that accrue to the product or service with its brand name, compared to the outcomes if the same product or service did not have a brand name. Following Aaker (1991), Brand Equity is conceptualized as the set of assets and liabilities linked to a brand, its name or symbol, which enhances or decreases the value provided by a product or service to the company and its customers. According to Keller's model (1993), Brand Equity occurs when the consumer is familiar with the brand and holds some favorable, strong and unique brand associations in memory. Authors like Aaker $(1991,1996)$ or Keller (1993) have concep- tualized Brand Equity as a multidimensional variable, while proposing measurement models characterized by the use of different variables related to consumer behavior, perceptions and preferences. Several theoretical models highlight the multidimensional nature of Brand Equity (Lassar et al. 1995; Agarwal and Rao 1996, Kim et al. 2009), as well as the sources of Brand Equity (Yoo and Donthu 2002; Pappu, et al. 2005). Among these models, those proposed by Aaker $(1991,1996)$ and Keller (1993), are an impor- tant reference in the marketing-related scientific community, providing a complete and integrating approach of the Brand Equity concept (Yoo and Donthu 2001; Pappu et al. 2005, 2007; Jung and Sung 2008). For this reason, in study we have chosen the model proposed by Aaker (1991), as it is the most commonly cited, as well as probed in a number of empirical investigations (Yoo et al. 2000; Faircloth et al. 2001; Atilgan et al. 2005). Thus, following the theoretical model proposed by Aaker (1991), we propose a model of formation of Brand Equity which incorporates four dimensions, such as brand awareness, perceived quality, brand associations and brand loyalty.

Our study aims to analyze the consequences of store Brand Equity on consumer behavior, such as the consumer purchase intention (Burke and Schoeffler 1980; Wilson 1981). There is empirical evidence which indicates that store Brand Equity influences the purchasing decisions of consumer (Ashil and Sinha 2004; Chang and Liu 2009). Numerous researchers have demonstrated that Brand Equity increases the probability of brand choice, purchase intent and willingness to pay premium prices (Erdem et al. 2002; Netemeyer et al. 2004). More specifically, they note a positive significant relation between dimensions of Brand Equity, brand preference and purchase intention (Cobb-Walgren et al. 1995; Myers 2003). This paper examines whether the store brands' purchase intention is related to the different sources of Brand Equity, and seeks to provide more in-depth understanding of the relationship among these components. The store Brand Equity conceptual framework is depicted in Figure 1. 
Figure 1

\section{Conceptual framework of store Brand Equity}

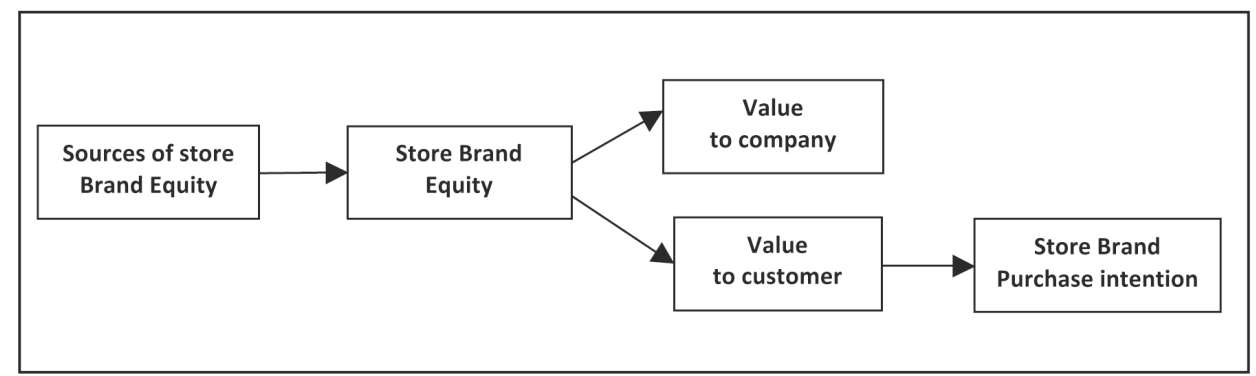

Source: Own elaboration

\subsection{The store brand equity}

\section{A. The conceptualization of store Brand Equity}

Store brands, also called private brands, own brands, retailer brands, wholesale brands and distributor's brands have drawn academic and managerial attention, in parallel with their growing market share. Following the definition given by the American Marketing Association, it can be defined as the brand which identifies the goods and services of a retailer and differentiates them from the competitors. Store brands enable retailers to build a high value proposition and offer consumers a range of lower priced products, that is, store brands help retailers to compete profitably in the price-sensitive segment (Corstjens and Lal 2000).

However, store Brand Equity concept is a recent view of the value created by retail brands. These brands benefit consumers by providing them a competitive alternative to manufacturer brands based on lower prices, due to their lower manufacturing and overhead costs, their less expensive packaging and the lack of advertising (Cunningham et al. 1982; Dick et al. 1995). Store brands generally use price as the driving force behind their own marketing mix (Beristain et al., 2011); however store brands have evolved throughout time and nowadays are no longer simply category killers; and furthermore some of them positioning as premium price options (De Wulf 2005). There is little research on store brands applying Aaker's $(1991,1996)$ Brand Equity model, in order to assess the influence of its dimensions or sources on purchase intention. A synthesis of the most relevant literature about the relations between Aaker's proposed dimensions of Brand Equity applied to store brands are summarized in Table 1. 
Table 1

Dimensions of brand equity applied to store brands identified in previous literature

\begin{tabular}{lll}
\hline \multicolumn{1}{c}{ Authors } & \multicolumn{1}{c}{$\begin{array}{c}\text { Variables related with store Brand } \\
\text { Equity }\end{array}$} & \multicolumn{1}{c}{ Contribution } \\
\hline $\begin{array}{l}\text { Collins-Dodd and } \\
\text { Lindley (2003) }\end{array}$ & Store image, store brand price & $\begin{array}{l}\text { Store image and store brand price are two } \\
\text { key antecedents of store brand equity. }\end{array}$ \\
\hline $\begin{array}{l}\text { Ailawadi and } \\
\text { Keller (2004) }\end{array}$ & $\begin{array}{l}\text { Retailer image, brand assortment, } \\
\text { private label }\end{array}$ & $\begin{array}{l}\text { Retailer brand equity influences store } \\
\text { brands' equity. Private labels help buil- } \\
\text { ding retailer brand equity. }\end{array}$ \\
\hline Beristain and & $\begin{array}{l}\text { Store brand perceived quality, store } \\
\text { brand loyalty, store brand aware- }\end{array}$ & $\begin{array}{l}\text { Store image influences store brand equi- } \\
\text { ty, essentially through store commercial } \\
\text { and strategic image. }\end{array}$ \\
& $\begin{array}{l}\text { ness, store social image, store mar- } \\
\text { keting image, store strategic image, }\end{array}$ \\
store price image. & $\begin{array}{l}\text { Store image, product signatu- } \\
\text { reness, consumer value, private } \\
\text { brands }\end{array}$ & $\begin{array}{l}\text { Store image and product signatureness } \\
\text { influence store brand perceived quality } \\
\text { and purchase intention }\end{array}$ \\
\hline Bao et al. (2011) & $\begin{array}{l}\text { Store brand awareness, store } \\
\text { brand image, intention to buy, re- } \\
\text { tail brand choice. }\end{array}$ & $\begin{array}{l}\text { Store brand awareness and store brand } \\
\text { perceived quality show the higher in- } \\
\text { fluence on store brand equity }\end{array}$ \\
\hline $\begin{array}{l}\text { Jara and Cliquet } \\
\text { (2012) }\end{array}$ & $\begin{array}{l}\text { Store brand image, store image, } \\
\text { store loyalty, store awareness sto- } \\
\text { re perceived quality. }\end{array}$ & $\begin{array}{l}\text { Reciprocal influence between retailer or } \\
\text { store image and store brand image }\end{array}$ \\
\hline $\begin{array}{l}\text { Bigné et al. } \\
\text { (2013) }\end{array}$ & $\begin{array}{l}\text { Retail brand equity, store loyalty, } \\
\text { store accessibility }\end{array}$ & $\begin{array}{l}\text { Strong brand equity and store accessibi- } \\
\text { lity create and enhance store loyalty. }\end{array}$ \\
\hline $\begin{array}{l}\text { Swoboda et al. } \\
\text { (2013) }\end{array}$ & & \\
\hline
\end{tabular}

Source: Own elaboration

Following Aaker (1991, 1996) Brand Equity is a multidimensional concept, which comprises five components or dimensions -brand awareness, brand image or brand associations, perceived quality, brand loyalty and finally, other assets linked to the brand-. The extension of Aaker's model is based on the premise that branding may be applied to store brands, since consumers perceive them as genuine brands, combining their attributes of awareness, image and price. Hence, our proposed theoretical model is an application of Aaker's customer-based brand equity model, replacing brand equity with store Brand Equity, based on that branding could be applied to store Brand Equity.

\section{B. The components of store Brand Equity}

\section{B.1. Store brand awareness}

Brand awareness relates to the likelihood that a brand name will come in the consumer mind and the ease with it does so (Keller 1993). Following Aaker (1991) and Keller (1993) 
two components determine brand awareness: brand recognition -requiring a brand wellknown by consumers- and brand recall -testing consumers' ability to remember brand names according to a specific product category. Authors, like Rossiter and Percy (1987) also state that brand awareness comprises the consumer's ability to recognize and recall a brand into a give product category. The role of the dimension brand awareness in Brand Equity depends on the level of noticeability that is achieved by a brand in the marketplace. So, the higher the level of awareness, the more dominant is the brand, increasing the likelihood that this brand is considered in many purchase situations. Hence, enhancing brand awareness increases the probability that a brand will be in the consideration set (Nedungadi 1990). Regarding store brands, having the same brand name and package design for products in a wide array of categories across the store, strengthens brand awareness and the recall of the store or retail brand and may facilitate the consumer's purchasing decision (Dhar and Hoch 1998). Finally, following Dodds et al. (1991), consumers are more likely to rely on store brands' familiar information cues, rather than in a good price-quality relationship in order to evaluate product's value. Therefore, this hypothesis is posed:

$H_{0}:$ Store brand awareness has a positive influence on purchase intention

\section{B.2. Store brand perceived quality}

Consumers perceive any product as a set of attributes which may be used to infer its quality (Keller 1993). According to Aaker (1991) perceived quality is an intangible overall feeling about a brand, usually based on underlying dimensions. Thus, perceived quality is related to consumers' subjective perception of a product or brand attributes involved in the decision-making process. Following Zeithaml (1988), the perceived quality is the global outcome of the experience of the different sensory stimuli that the consumer is rather unable to analyze, but that can be used as a global assessment of the competitive quality of a brand. According to Aaker (1991, 1996), perceived quality is conceptualized as an intangible overall evaluation of a brand, usually based on some underlying dimensions, such as the products' characteristics attached to a brand like reliability and performance.

Store brands competitive positioning derives from consumers' perception of store brands as convenient price options and have prioritized price (Ailawadi et al. 2008). However, more recent trends have been characterized by a stronger orientation toward quality and value proposition similar to manufacturer brands (Hoch and Banerji 1993). Although store brands seem to offer a better price-quality relationship than manufacturer brands, their competitive positioning differs in terms of the quality level offered (Soberman and Parker 2006). On the other hand, previous literature indicates that store brands suffer from a poor low-quality image, which is probably fostered by the widespread use of poor looking packaging, inexpensive packages and a lack of an attractive brand image, due to a poor marketing investment and to their market positioning (Richardson et al. 1994). The importance of store brands' perceived quality is a key factor, given that the better the store brand is positioned in terms of quality, the more likely is to be purchased (Ailawadi and Keller 2004). Perceived quality is a main determinant of store brands' success (Sprott and Shimp 2004) and it was found to have substantial exert on purchase intention (Bao et al. 2011). So, one of the sources of store brand success is perceived quality, which leads to store differentiation and store loyalty (Burt and Sparks, 2002). A number of authors like Sethuraman 
(2000) or Hoch and Banerji (2000) have remarked that perceived quality is the main factor in store brands' purchase decision. Perceived quality has a significant positive effect on consumer's purchase intention (Farquhar 1989). Then, we pose the following hypothesis:

$H_{1}$ : Store brand perceived quality has a positive influence on purchase intention

\section{B.3. Store brand loyalty}

From a behavioral perspective, brand loyalty is defined as the degree to which a consumer concentrates its purchases over time on a particular brand within a product category (Schoell and Guiltinan 1990). Brand loyalty adds considerable value to a brand because it provides a set of habitual buyers for a long period of time (Aaker, 1991), so customer loy- alty generates numerous benefits for a brand. This study conceptualizes brand loyalty on the basis of consumer perception. Thus, following Aaker (1991) brand loyalty is conceptualized as a situation which reflects how likely a customer will be to switch to another brand, es- pecially when that brand makes a change, either in price or features. Keller (2003) refers to brand loyalty as the nature of customer-brand relationship. These definitions highlight that brand loyalty is a core dimension of Brand Equity (Aaker, 1991). Customers who are loyal to a particular brand buy more and are willing to pay higher prices (Zeithaml et al. 1996).

Customer loyalty is a critical goal for retailers because of an increasingly competitive retail environment and low customer switching costs (Wallace et al. 2004). Store branding is extremely important in helping influence consumer perceptions and drive store choice and loyalty (Ailawadi and Keller 2004). There is empirical evidence suggesting that once the consumer has tried store brands, increases store brand proneness, engendering store brand loyalty and enhancing the likelihood of purchasing store brands (Steemkamp and Dekimpe 1997). However, customers remain loyal to store brands only if the brands maintain a favorable image. Store brand recognition in some categories may constitute an element of differentiation for the retailer and foster consumers' brand loyalty (Steemkamp and Dekimpe 1997). Finally, some researchers posit that brand loyalty has a direct and positive role in affecting Brand Equity and purchase intention (Yoo et al. 2000; Atilgan et al. 2005). Thus, this set of considerations leads us to the following hypothesis:

\section{$\mathrm{H}_{2}$ : Store brand loyalty has a positive influence on purchase intention}

\section{B.4. Store brand price image}

Price has often been considered as an indicator of product or service cost (Kotler and Armstrong 2008). Following Ailawadi and Keller (2004), price represents the monetary ex- penditure that the consumer must incur in order to make a purchase. (Ailawadi 2008). As it was explained before, store brands value proposition is strongly influenced by price, and unsurprisingly they are perceived as cheaper alternatives than manufacturer brands (Beristain et al. 2011). For this reason store brand price image has been selected as the brand association in our research. Store brands low-price positioning derives from the consumers' perception of store brands as a convenient price option -compared to manufacturer brands-, focusing on a low-price proposition. So, the price gap in comparison with manu- 
facturer brands is a key variable in the store brands purchase process (Aaker 1996), and retailers develop strategies which intend to emphasize the good value for money in their choice (Rangaswamy et al. 1993, Baltas 1997). A number of studies have remarked the benefits created by store brands, related to savings linked to their purchase, highlighting that the need of saving is the main factor for buying store brands (Raju et al. 1995). So, price plays an essential role in the configuration of store Brand Equity proposition (Aaker 1991); and thus, we propose that the perception of an affordable, adequate or relatively low price has a positive influence on purchase intention (Richarson et al. 1996). This set of considerations leads us to the following hypothesis:

$H_{3}$ : The store brand price image - as adequate affordable prices- has a positive influence on purchase intention

\section{B.5. Store image}

The rationale of our research is that store brands' image positioning is based on that of the store, suggesting that influencing store Brand Equity is due to a large extent by retailer or store image, and consequently by store reputation and store commercial (Collins-Dodd and Lindley, 2003; De Wulf et al., 2005; Beristain and Zorrilla, 2011). The reason may be that retailer or store image would play a key role as a customer guarantee when information of the manufacturer is not provided. This way, customers would rely on the store image, which decreases the perceived risk of purchasing store brands. This proposed model will allow us identify the influence of store image on store Brand Equity and consequently on store brands' purchase intent, given that the extrinsic cue provided by the store image should be more relevant for store brands than for manufacturer brands. Following Ailwadi and Keller (2004) the image of the retailer or the store in the minds of consumers is the basis of the store Brand Equity; and thus, retailer and store image becomes an important base for their store Brand Equity, by influencing consumer preferences and purchasing behavior. Therefore, we propose considering these store image variables in the customer-based store Brand Equity model, as- suming that store reputation and store commercial image, would influence store Brand Equity.

\section{B.5.1. Store reputation}

Store reputation may be defined as a set of associations linked to a determinate store or retailer which make up the overall store image (Keller 1993). Store reputation is expressed in terms of a store's attributes perceived and assessed by consumers (Devlin et al. 2003). Several authors have analyzed store reputation including variables like store personality and its global corporate image (Floor 2006). In this research we have considered store reputation these variables both related with the social image of the store or retailer, since following authors like Turban and Greenging (1996) or Brown and Dancing (1997), stores can be perceived as firms, linking the store image with aspects such as the company's behavior and commitment to society. Through its influence on customers' preferences and purchase behavior, store reputation becomes a key variable of the store Brand Equity (Keller 2003). Therefore, we pose the following hypothesis:

\section{$H_{4}:$ The store reputation has a positive influence on purchase intention}




\section{B.5.2. Store commercial image}

Literature provides numerous references to the positive effect of store commercial image on store Brand Equity and purchase intention (Semeijn et al. 2004, Vahie and Paswan 2006). The store commercial image has generally been defined as the way in which the store is defined in the consumer's mind, partly by the functional qualities and partly by the psychological attributes of the store (Thompson and Chen 1998; Bloemer and Ruyter 1998). Most authors have centre don functional attributes of the store, as the quality of products offered and variety of the assortment, the services provided to customers, the product assortment, the physical facilities, internal environment or the good relation of val- ue for money (Chowdhury et al. 1998; Erdem et al. 1999; Jin and Kim 2003). A number of studies highlighted that consumers' perceptions of a store internal atmosphere and environ- ment can influence consumers' decision whether or not they visit a store, how much time they spend in it, how much money they spend there and the quantity purchased (Grewal et al. 2003). So, consumers use these cues to form overall evaluations affecting their attitude toward the store brand (Semeijn et al. 2004). Store commercial image can play a crucial role in building store Brand Equity; and there is empirical evidence showing that a positive store commercial image positively influences store brand proneness and purchasing decision (Porter and Claycomb 1997). Thus, the following research hypothesis is posed:

$H_{5}$ : The store commercial image has a positive influence on purchase intention

The proposed causal relations are depicted in Figure 2.

Figure 2

\section{Proposed theoretical model}

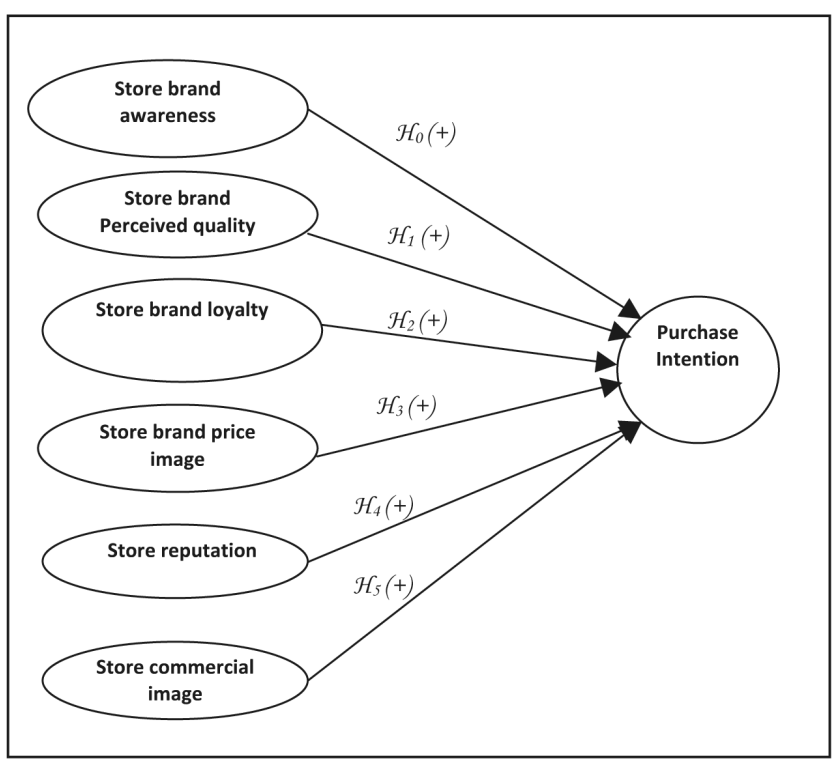

Source: Own elaboration 


\section{METHODOLOGY}

\subsection{Selection of variables}

The reality of store brands is enormously rich and complex, since store brands are available in several commercial retailing formats (Kapferer, 2008), so it requires the selection of a specific research area in order to test the hypothesis raised. Our research universe comprises Spanish consumers who purchase store brand products in supermarkets, hypermarkets, department stores or discount stores. We followed some criteria in order to select the retailers. In first place we selected a number of different retail formats, focusing on the leading companies in the Spanish retailing system, considering their total revenue in year 2012 (Worldpanel Distribución 2012). Secondly, we choose retailers who offer store brands to consumers. This way, we selected the retailers Mercadona -supermarket format-, Carrefour and Eroski -hypermarket format-, Dia - as a discount store- and finally El Corte Inglés - as department store format. We also considered five major retailers based on their availability and familiarity to customers. Lastly, it should be remarket that our research did not consider other retailing formats with a lower revenue volume or lacking an own store brand.

Based on various scales of measurement provided by the literature on the theoretical analysis made, we created a set of items, which were measured using the classic Likerttype 1-5 scale. First, in order to measure store brand awareness, we used items proposed by Aaker (1996) and by Netemeyer et al. (2004), which refer to the general knowledge the consumer has about a brand and to their ability to distinguish and recognize a brand compared to other competitive brands. Regarding store brand perceived quality, it was measured using the scale proposed by Dodds et al. (1991), which assess the perceived quality without regarding the attributes specific to a particular product category, and which aims to gather the consumer's overall assessment on the excellence of a product or brand. For measuring store brand loyalty, we use the scale proposed by Yoo et al., (2000), which analyzes whether the consumer is considered loyal to a particular brand and if the brand is its first option, even if he would not buy other brands when this brand is not available at the point of sale. For measuring store brand price image we used the scale proposed by Yoo et al. (2000), since it considers the price perception from the consumers' standpoint, considering that a higher value of these items mean that consumers perceive prices as more affordable and suitable to the household budget. The store reputation was assessed using some items suggested by García de los Salmones et al. (2005), and Beristain and Zorrilla (2011) based on the perceptions of consumers about the ethical and social corporate behavior, following the research line about the influence of the corporate social responsibility on consumers' behavior (Handelman and Arnold, 1999). The store commercial image was measured by using items proposed by Beristain and Zorrilla (2011), to which there has been added items related to added services offered by the store, proposed by Aaker (1996) and Chowdhury et al. (1998). Finally, for measuring consumer purchase intention we used items proposed by Netemeyer et al. (2004). The variables and indicators used in the study are summarized in Table 2. 
Table 2

\section{Variables and reflective indicators}

\begin{tabular}{|c|c|}
\hline ss & rs \\
\hline $\begin{array}{l}\text { Store Brand Awareness } \\
\text { Aaker (1996), Netemeyer } \\
\text { et al. (2004) }\end{array}$ & $\begin{array}{l}\text { AW1: I am able to distinguish and recognize store brand X among } \\
\text { other brands in the point of sale } \\
\text { AW2: I associate products of store brand X to positive characteristics } \\
\text { (ex. good prices) } \\
\text { AW3: Buyer of products of store brand X know how to buy (buy with } \\
\text { common sense) } \\
\text { AW4: It gives me confidence buying a store brand X }\end{array}$ \\
\hline $\begin{array}{l}\text { Store Brand Perceived } \\
\text { Quality } \\
\text { Dodds et al. (1991) }\end{array}$ & $\begin{array}{l}\text { QAL1: The products of store brand } X \text { have a high quality } \\
\text { QAL2: The products of store brand X are reliable/trustworthy } \\
\text { QAL3: The products of store brand X give me the result I'm looking } \\
\text { for }\end{array}$ \\
\hline yalty & $\begin{array}{l}\text { LOY1: I consider myself a loyal consumer to the store brand X products } \\
\text { LOY2: When it comes to buying, my first purchase option is store brand } \\
\mathrm{X} \\
\text { LOY3: I intend to keep on buying store brand X. }\end{array}$ \\
\hline $\begin{array}{l}\text { Store Brand Price image } \\
\text { Yoo et al. (2000) }\end{array}$ & $\begin{array}{l}\text { SPR1: The prices of store brand } X \text { are affordable for most consumers } \\
\text { SPR2: The prices of store brand } X \text { are adequate for household budget }\end{array}$ \\
\hline $\begin{array}{l}\text { Store Reputation } \\
\text { Handelman and Arnold } \\
\text { (1999), García de los } \\
\text { Salmones et al. (2005), Be- } \\
\text { ristain and Zorrilla (2011) }\end{array}$ & $\begin{array}{l}\text { SRE1: } X \text { is a company concerned about environment } \\
\text { SRE2: } X \text { is a company committed with society (ex. donations, collabo- } \\
\text { rates with NGOs, etc) } \\
\text { SRE3: } X \text { is a company which behaves in an ethical and honest way } \\
\text { SRE4: } X \text { is a company that cares about consumers' health and welfare }\end{array}$ \\
\hline $\begin{array}{l}\text { Store Commercial Image } \\
\text { Aaker (1996), Chowdhury } \\
\text { et al. (1998), Beristain and } \\
\text { Zorrilla (2011) }\end{array}$ & $\begin{array}{l}\text { SCOIM1: Store X offers a wide range of products } \\
\text { SCOIM2: Store X offers products with high quality } \\
\text { SCOIM3: The store X offers services that I'm looking for (ex. Pay } \\
\text { over time, products' return, etc.) }\end{array}$ \\
\hline $\begin{array}{l}\text { ention } \\
\text { al., (2004) }\end{array}$ & $\begin{array}{l}\text { INT1: I would b } \\
\text { INT2: I am likel }\end{array}$ \\
\hline
\end{tabular}

Source: Own elaboration

\subsection{Sampling and fieldwork}

The respondents were deliberately not asked to select the store or retailer for which they have detailed knowledge or shopping experience, in order to get closer to authentic shopping situations, where customers make choices from a set of alternatives. Thus, we proceeded with a random sampling among customers, requesting information on one single store brand of the selected retailers -namely store brands Día, Eroski, El Corte Inglés, Carrefour and Hacendado-, and not regarding a specific product category, as for example AW4 "It gives me confidence buying store brand Dia" or SOIM1 "Dia offers a wide range of products". 
Each of the items in the questionnaire is anchored on a five-point Likert scale to measure the respondent's agreement to the item posted, ranging from 1-strongly disagree to 5 -strongly agree. The information was captured through a structured on-line questionnaire and the fieldwork was done in May 2012, with a sampling error of 5.2 per cent, at a confidence level of $95 \%$ under hypothesis $p=q=0,5$. A random sampling technique was performed to select the participants, obtaining a total amount of 362 valid responses. The final part of the questionnaire collected socio-demographic data of the respondents (Table 3), obtaining 362 valid respondents, gathering the following number or valid questionnaires for each store brand: 77 questionnaires corresponding to Eroski, 75 corresponding to Carrefour , 74 regarding El Corte Inglés, 69 corresponding to Mercadona and 67 related to Dia.

Table 3

Sample description

\begin{tabular}{llc}
\hline \multicolumn{1}{c}{ Variables } & \multicolumn{1}{c}{ Cathegory } & Percentage (\%) \\
\hline \multirow{2}{*}{ Gender } & Female & 32.32 \\
& Male & 67.68 \\
\hline \multirow{4}{*}{ Age } & $18-30$ years & 21.4 \\
& $31-45$ & 35.2 \\
& $46-60$ & 31.9 \\
& $>60$ & 11.5 \\
\hline \multirow{3}{*}{ Income level } & $<1.500$ & 24.8 \\
(Euros/ month) & $1.501-2.500$ & 39.5 \\
& $2.501-4.000$ & 31.2 \\
& $>4.000$ & 4.5 \\
\hline \multirow{4}{*}{ Studies level } & None & 0.61 \\
& Primary Education & 42.07 \\
& Secondary Education & 38.41 \\
& University Education & 18.30 \\
Store Brands Pur- & Doctorate (Phd) & 0.61 \\
chase frequency & 1 purchase/ week & 23.6 \\
& 1 purchase / 15 days & 43.7 \\
\hline
\end{tabular}

Source: Own elaboration

\section{RESULTS}

\subsection{Analysis of the measurement model}

Structural Equation Modeling (SEM) was carried out in order to analyze the proposed model, by using Amos 18.0 which provides with a confirmatory factor analysis and show a clear factorial structure for constructs considered. The first analysis revealed the need to remove one item from the initial scale in order to measure the dimensions. One item from the initial proposed scale was deleted, more specifically an item concerning store brand 
loyalty (LOY3). When having removed this indicator, the results of the confirmatory factor analysis demonstrated a reasonable fit of the five-dimension model to the data on the basis of fit statistics (Table 4). Confirmatory factor analyses were employed to address the issues of dimensionality, convergent and discriminant validity (Anderson and Gerbing 1988). Our confirmatory factorial analysis shows that all standardized loadings are significant, with a reliability level of $95 \%$ and reach values up to 0.5, except for item AW1 which should be considered in a further research. These results reveal the strong convergent validity (Steenkamp and Trijp 1991; Fornell and Larcker 1981; Lévy-Mangín 2001; Diamantopoulos and Siguaw 2006), like the absolute fit measures reveal. In relation with the analyses of internal consistency and reliability, Cronbach Alpha, composite reliability coefficients and analysis of the extracted variance exceeded were calculated. We obtained Cronbach Alpha acceptable values of 0.7, 0.8 and 0.7 as suggested Anderson and Gerbing (1988) or Hair et al. (2006). Following previous literature, Composite reliability coefficients that exceed a value of 0.5 confirm the internal reliability of the construct considered (Bagozzi and Yi 1989). In relation with the analysis of extracted variance exceeded, that should have close values to 0.5 we also obtain acceptable values for all constructs (Hair et al. 1999). None of the correlation coefficients were equal to or above 0.9 , providing empirical support for discriminant validity (Campbell and Fiske 1959; Wu and Lin 2000).

Table 4

Factor loadings of latent variables and Indicators of Internal Consistency and Reliability

\begin{tabular}{|c|c|c|c|c|c|}
\hline Variable & Indicators & $\begin{array}{l}\text { Loadings } \\
\text { (Lambda) }\end{array}$ & $\begin{array}{c}\text { Cronbach } \\
\text { Alpha }\end{array}$ & $\begin{array}{l}\text { Composite } \\
\text { Reliability }\end{array}$ & AVE \\
\hline $\begin{array}{l}\text { Store brand } \\
\text { awareness }\end{array}$ & $\begin{array}{l}\text { AW1 } \\
\text { AW2 } \\
\text { AW3 } \\
\text { AW4 }\end{array}$ & $\begin{array}{l}0.361 \\
0.773 \\
0.687 \\
0.795 \\
\end{array}$ & 0.741 & 0.759 & 0.566 \\
\hline $\begin{array}{l}\text { Store brand } \\
\text { perceived quality }\end{array}$ & $\begin{array}{l}\text { QAL1 } \\
\text { QAL2 } \\
\text { QAL3 }\end{array}$ & $\begin{array}{l}0.839 \\
0.873 \\
0.811\end{array}$ & 0.876 & 0.879 & 0.708 \\
\hline Store brand loyalty & $\begin{array}{l}\text { LOY1 } \\
\text { LOY2 }\end{array}$ & $\begin{array}{l}0.903 \\
0.862 \\
\end{array}$ & 0.874 & 0.876 & 0.779 \\
\hline $\begin{array}{l}\text { Store brand price } \\
\text { image }\end{array}$ & $\begin{array}{l}\text { SPR1 } \\
\text { SPR2 }\end{array}$ & $\begin{array}{l}0.724 \\
0.950\end{array}$ & 0.814 & 0.830 & 0.713 \\
\hline Store reputation & $\begin{array}{l}\text { SRE1 } \\
\text { SRE2 } \\
\text { SRE3 } \\
\text { SRE4 }\end{array}$ & $\begin{array}{l}0.676 \\
0.768 \\
0.782 \\
0.762\end{array}$ & 0.834 & 0.835 & 0.560 \\
\hline $\begin{array}{l}\text { Store commercial } \\
\text { image }\end{array}$ & $\begin{array}{l}\text { SCOIM1 } \\
\text { SCOIM2 } \\
\text { SCOIM3 }\end{array}$ & $\begin{array}{l}0.562 \\
0.888 \\
0.543 \\
\end{array}$ & 0.716 & 0.712 & 0.489 \\
\hline Purchase intention & $\begin{array}{l}\text { INT1 } \\
\text { INT2 }\end{array}$ & $\begin{array}{l}0.914 \\
0.951\end{array}$ & 0.930 & 0.930 & 0.869 \\
\hline
\end{tabular}

Source: Own elaboration 
The overall fit measures indicate that this model shows a proper fit. According to the results obtained for the structural modeling adjustment (Table 5). Chi-square reaches a value of 272.711 ( $\mathrm{DF}=149, \mathrm{p}<0.001$ ), with a significant level. So, chi-square, could be considered a reliable indicator of model fit (Bollen 1989; Hair et al. 1999). Other absolute measures of a modeling adjustment (Goodness of Fit Index and Root Mean Square Error of Approximation) show good results, given that the former reaches the threshold of 0.9 and the later shows a value lower than 0.05 value. The measures of incremental fit and parsimony, also indicate a proper fit, taking into consideration that the Incremental Fit Index (IFI), Tucker-Lewis Index (TLI) and the Comparative Fit Index (CFI) reaches a threshold superior 0.9 and the normed Chi-Square shows a value of 1.830, that is, superior than 1 and lower than 2 (Qiu 2003). Furthermore, reliability rate achieved $(\mathrm{R} 2=0.668)$ by the structural equation in the model is high (Hair et al. 1999).

Table 5

Structural Modeling Adjustment Indexes

\begin{tabular}{lc}
\hline \multicolumn{1}{c}{ Absolute Fit Measures } & Final scale \\
\hline Chi-square & 272.711 \\
\hline Degrees of Freedom & 149 \\
\hline Significant Level & 0.000 \\
\hline Goodness of Fit Index (GFI) & 0.933 \\
\hline Root Mean Square Error of Approx (RMSEA) & 0.048 \\
\hline \multicolumn{2}{c}{ Incremental Fit Measures } \\
\hline Adjusted Goodness of Fit Index (AGFI) & 0.906 \\
\hline Normed Fit Index (NFI) & 0.939 \\
\hline Incremental Fit Index (IFI) & 0.971 \\
\hline Tucker-Lewis Index (TLI) & 0.963 \\
\hline Comparative Fit Index (CFI) & 0.971 \\
\hline \multicolumn{2}{c}{ Parsimony Measures } \\
\hline
\end{tabular}

Source: Own elaboration

\subsection{Relationships among variables}

When analyzing the coefficients obtained, some important results must be highlighted (Table 6). In first place, store brand awareness, loyalty and perceived quality show a positive significant influence on store brand purchase intention, so our findings support three of the initial proposed hypotheses. Secondly, it should be remarked that store brand awareness it the variable with a higher effect on purchase intention $\left(\beta_{17}=0.655^{* *}\right)$-understood as famili- arity, recognition and recall by consumers-, followed by store brand loyalty $\left(\beta_{37}=\right.$ 
$0.379 * *)$. In third place, store brand perceived quality $\left(\beta_{27}=0.275^{* *}\right)$ shows the lower influence on store brand purchase intention. Thus, in terms of the effect size, store brand awareness seems to contribute the most to the formation of store Brand Equity and to its purchase intention.

These findings demonstrate that store brands follow a similar pattern to manufacturer brands, regarding the influence of the sources of Brand Equity in purchase intention. This results are in line with a number of previous research which remark that brand awareness (Cobb-Walgren et al. 2005; Pappu et al. 2005) or brand loyalty (Yoo et al. 2000; Tong and Hawley 2009) as the more influent variables. Finally, our findings do not find empirical envidence regarding the significance of store reputation $\left(\beta_{57}=0.048\right)$, store commercial image $\left(\beta_{67}=0.055\right)$ and store brand price image $\left(\beta_{47}=0.059\right)$ on store brand purchase intention. That is, we have not found sufficient empirical evidence to propose a significant relationship among store reputation, store commercial image or store brand price image and consumers' purchase intention.

Table 6

\section{Results of the structural model (standarized coefficients)}

\begin{tabular}{|c|c|c|c|}
\hline Causal Relationships among constructs & Estimate & $\mathrm{T}$ Value & $\begin{array}{l}\text { Hypothesis } \\
\text { conclusion }\end{array}$ \\
\hline Store brand awareness $\rightarrow$ Purchase intention & $\beta_{17}=0.655 * *$ & 2.852 & $H_{0}:$ supported \\
\hline $\begin{array}{l}\text { Store brand perceived quality } \rightarrow \text { Purchase } \\
\text { intention }\end{array}$ & $\beta_{27}=0.275 *$ & 1.732 & $H_{1}:$ supported \\
\hline Store brand loyalty $\rightarrow$ Purchase intention & $\beta_{37}=0.379 * *$ & 3.590 & $\mathrm{H}_{2}:$ supported \\
\hline Store brand price image $\rightarrow$ Purchase intention & $\beta_{47}=0.059^{\mathrm{ns}}$ & 0.907 & $H_{3}:$ no supported \\
\hline Store reputation $\rightarrow$ Purchase intention & $\beta_{57}=0.048^{\mathrm{ns}}$ & 0.657 & $H_{4}:$ no supported \\
\hline Store commercial image $\rightarrow$ Purchase intention & $\beta_{67}=0.055^{\mathrm{ns}}$ & 0.440 & $H_{5}:$ no supported \\
\hline $\begin{array}{l}\chi^{2}=272.711 \mathrm{df}=149 \mathrm{p}=.000 \\
\boldsymbol{R}^{2}(\text { Purchase intention })=0.668 \\
n s=\text { no significant } * * \text { significant }(p<0.05) ; \\
* \text { significant }(p<0.1)\end{array}$ & & & \\
\hline
\end{tabular}

Source: Own elaboration

Regarding the proposed research hypotheses, we can state that $H_{0}$ : Store brand awareness has a positive influence on purchase intention, may be supported considering the results obtained, with a significance level of the 0.05 percent, as well as $\mathrm{H}_{2}$ : Store brand loyalty has a positive influence on purchase intention. Considering the results obtained, $H_{1}$ : Store brand perceived quality has a positive influence on purchase intention, may be supported with a significance level of the 0.10 percent. However, the initial proposed hypotheses $H_{3}$ : The store brand price image, as affordable an adequate, has a positive influence on purchase intention, $H_{4}$ : The store reputation has a positive influence on purchase intention, as well as $H_{5}$ : The store commercial image has a positive influence on purchase intention, cannot be supported, since empirical evidence was not found. 
Figure 3

\section{Causal relationships (standarized coefficients)}

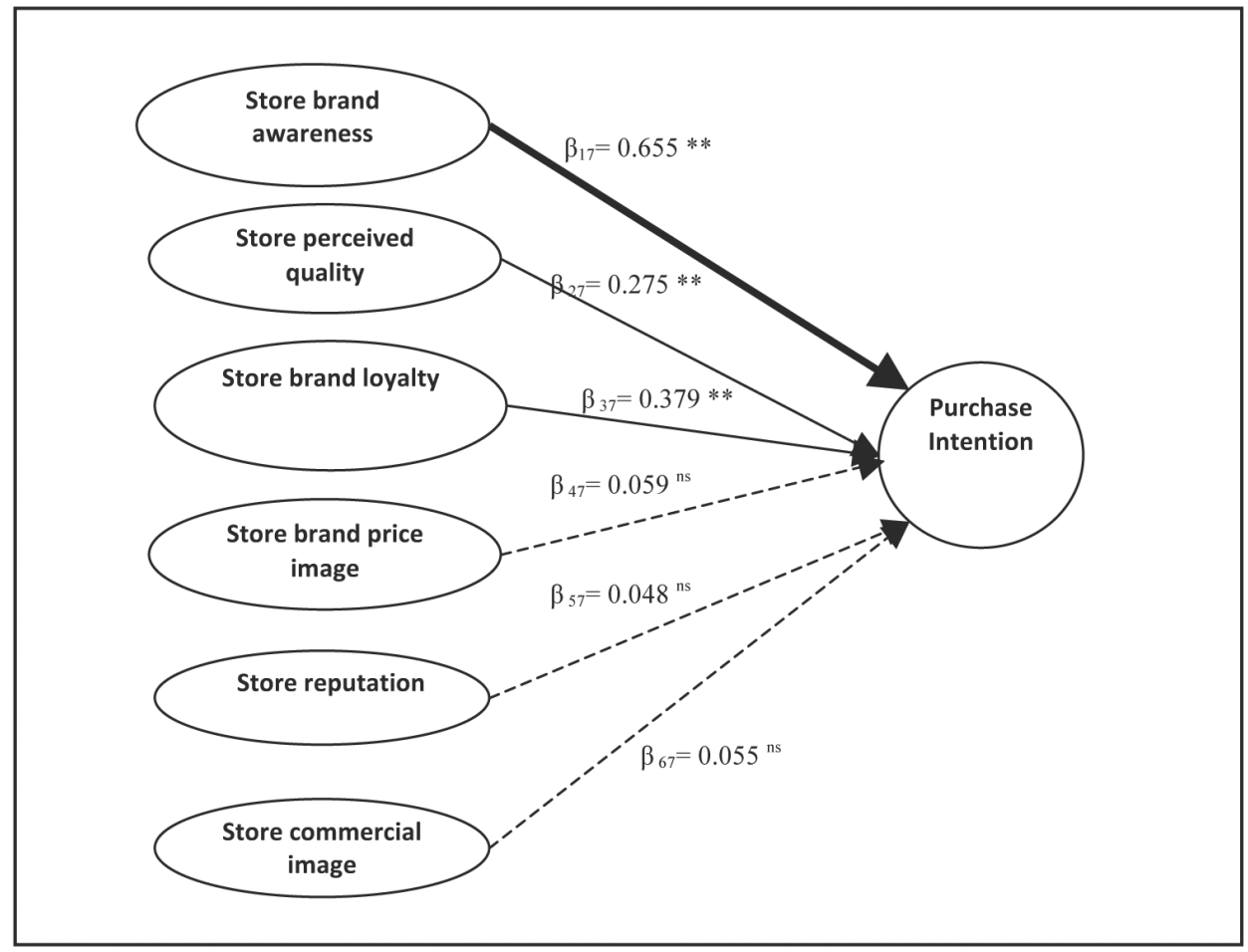

Source: Own elaboration

\section{DISCUSSION AND IMPLICATIONS}

There are many articles on Brand Equity centered on manufacturers' brands, whilst there are not as abundant researches on store Brand Equity. The present paper aims to contribute to this lack or research by analyzing the sources of store Brand Equity and their relationship to consumers' purchase intent. This is particularly interesting in a context of economic downturn, in which store brands are increasing their market share significantly.

One of our major findings is the positive and significant impact of store brand awareness in the purchase intent, to coincide with a number of previous studies (Richardson et al. 1994; Semeijn et al. 2004). Thus, store brand awareness, which is related to brand familiarity, recognition and recall, plays the most important role in enhancing consumers' purchase intention (Dursun et al. 2011). These results are in line with Jara and Cliquet (2012), stressing that brand awareness positively and directly influences consumers' response, being the main component in the creation of store Brand Equity. We understand that store brand, when being notorious, that is, well- known for consumers, recognizable and fami- 
liar, would play a role as customer guarantee. Therefore, a renowned store brand would be associated with a certain level of product quality sold under a retailer or store brand name. This way, consumers perceive the store brand in highly reliable, trustworthy, inspiring confidence and meeting their quality expectations (Ambler 1997). We believe that store brands' awareness -renowned and familiar store brand- is perceived in general terms as a guarantee; and consequently, consumers would perceive this store brand as caring about their needs and offering an acceptable quality (Dubois and Duquesne 1995; Del Río et al. 2002). These results are in line with Dodds et al. (1991) who suggested that consumers highly rely on the familiar information cues of the store brand in order to assess the product's worth; and with Baltas (1997) who stated that consumers seek for the guarantee that a familiar brand brings rather than the risks linked to lesser-known manufacturer brands.

Other major finding is the positive influence of store brand loyalty and store brand perceived quality on consumers' purchase intent. The influence of perceived quality is in line with previous literature, since numerous authors noticed that the most important driver of store brands share is their perceived quality (Hoch and Banerji, 1993; Sethuraman, 2000). In fact, the perceived quality gap or differential between store brands and manufacturer brands is a relevant issue, given that the better the store brand is positioned in terms of quality, the more likely it is to succeed (Ailawadi and Keller 2004). Consequently, there is a tendency today towards increasing perceived quality level of store brands in many countries (Huang and Huddleston 2009; Jara and Cliquet 2012).

Considering previous research which shows store image as a key variable on brand's purchase intention (Beristain and Zorrilla, 2011), it was expected a positive significant relationship between store image -store reputation and store commercial image- and customers' store brand purchase intention, despite no empirical evidence of its influence has been found. Our findings are similar to Beristain and Zorrilla (2011), who have not found sufficient empirical evidence in order to state the existence of a significant relationship between store social image and store Brand Equity. Therefore, we propose that store reputation and store commercial image may be considered as antecedents of the sources of store Brand Equity, given that they do not appear to impact the equity or value of store brands.

Regarding store brand price image, understood as consumers' perception of affordable and adequate prices, no empirical evidence is found of its significant influence in store brand purchase intent. As it was explained before, price sensitivity is one of the key factors that determine the consumer preference for store brands, and as many authors point out, consumers are more price sensitive in economic crisis (Estelami et al. 2001). The reason for these results may be that good value for money or a low price is an intrinsic characteristic of store brands, compared to manufacturer brands, since store brands have been traditionally positioned as focused to price-sensitive consumers (Sinha and Batra 1999); and therefore customers expect store brands to have low prices per se. Other explanation to these results may be that most frequent store brand consumers give less consideration to extrinsic attrib- utes of store brands -such as price- when it comes to make their purchasing decisions (Dick et al. 1995). Further explanation may be that the variable which must be analyzed is value for money, rather than whether the price is perceived as affordable and adequate.

Our findings show that low price positioning is no sufficient nowadays to bring value to customers or to develop a long-term relation with consumers, despite it is important to maintain an adequate price image, in accordance with retailers' price positioning. 
From the results obtained, we propose some useful insights for retailers. First recommendation guidance for retailers is to increase store knowledge, enhancing recognition and spontaneous recall, in order increase store awareness (Bigné et al., 2001). In second place, because of the higher influence of brand awareness in consumers' store brand purchase intent, retailers will benefit their store brands if they are present and available in as many product categories as possible. This way, store brands' awareness and familiarity will increase its visibility and familiarity to consumers, and therefore, the purchase intention will be increased, which is in the line with the research made by Sayman and Raju (2004). One major implication of our research is that retailers and managers should focus their efforts on increasing store brands' familiarity. Furthermore, in order to increase store brands' sales, retailers should put more emphasis on their brands' awareness, instead of focusing brand positioning as cheap or affordable brands (Bao et al. 2011). Advertising investments must be pursued to reinforce the memory of the store brand name and its distinctive features. Some authors like Dick et al. (1995) suggest enhancing familiarity by strengthening the advertising and promotional campaigns, using in-store display advertising, informational material at the point of sale, product aisles and offering sample store brand products inside the store. Retailers may also use coupons, price deals and other promotions in order to encourage the trial of their store brands (Sprott and Shimp 2004).

We find important that if a retailer decides to offer store brands, he should tell consumers, putting special emphasis on the relationship between the store brand and the retailing chain. Additionally, we suggest that for enhancing store brands' awareness, the retailer should increase the exposure of consumers to these brands, inside and outside of the point of sale. Therefore, in terms of actions which may be performed inside the store, there should be considered the merchandising and the sales network communication. We should remark the relevance of a good store brand display in the lineal, as well as the information and service provided by the salespeople regarding the characteristics and qualities of the store brand. These marketing actions will result in a higher level of familiarity and recognition. As for the actions which may developed outside the store, the presence of the store brand in catalogs and sales brochures will also enhance brand awareness.

Furthermore, retailers should continue working in order to increase consumer loyalty to their store brands, by launching marketing programs which foster customer loyalty, and in last term, customer loyalty to their stores. Finally, retailers should also create value for consumers through the objective quality of store brands, given that as far as store brands are being perceived as of equal quality -or even of better quality- than the manufacturer's brands, retailers will achieve increasing customers' purchase intention.

\section{LIMITATIONS AND FUTURE RESEARCH GUIDANCE}

As for the main limitations of our study, first we should notice that this empirical research has focused in Spain, as well as to a limited number of store brands, which causes serious problems when extrapolating results to the set of store brands. In second place, we should make reference to the small simple size. Moreover, it is remarkable that our study has analyzed a number of variables previously proposed in literature, ignoring other important store brand variables, such as the perceived risk, the typology of buyer or even 
the product category considered. In this regard, many authors have shown that the store brand purchase intention depends on product category (Batra and Sinha 2000; Caplliure et al. 2009). Taking into account research findings, we suggest considering store image variables, namely store reputation and store commercial image as antecedents of the sources of store brand equity in further research on the topic. Furthermore, our research approach raises the question of whether the results can be generalized to other retailing sectors or event to other countries. Hence, our study has focused and tested only in the context of large retailing in one specific country, so caution must be exercised in generalizing from these findings and further research are also needed to avoid some limitation.

\section{REFERENCES}

Aaker, D.A., 1991. Managing Brand Equity Capitalizing on the Value of Brand Name. New York: The Free Press.

Aaker, D.A., 1996. Measuring Brand Equity Across Products and Markets. California Management Review, 38 (3), 102-120.

Aaker, D.A. and Alvarez, R., 1995. Estatura de la marca: medir el valor por productos y mercados.

Harvard Deusto Business Review, 69 (November-december), 74-87.

Ailawadi, K.L. and Keller, K.L., 2004. Understanding retail branding: conceptual insights and re- search priorities. Journal of Retailing, 80, 331-342.

Ailawadi, K.L., Pauwels, K. and Steenkamp, J-B., 2008. Private label use and store loyalty. Journal of Marketing, 72 (3), 19-30.

Agarwall, M.K. and Rao, V.R., 1996. An Empirical Comparison of Consumer-Based Measures of Brand Equity. Marketing Letters, 7 (3), 237-247.

Ambler, T., 1997. How much of Brand Equity is explained by trust. Management Decision, 35(4), 283-292.

Anderson, J. C. and Gerbing, D. W., 1988. Structural equation modeling in practice: A review and recommended two step approach. Psychological Bulletin, 103 (3), 411-423.

Atilgan, E., Aksoy, S. and Akinci, S. ,2005. Determinants of the Brand Equity: A Verification Ap- proach in the Beverage Industry in Turkey. Marketing Intelligence and Planning, 23 (2/3), 237- 248.

Bagozzi, R.P. and Yi, Y. ,1988. On the evaluation of Structural Equation models. Journal of the Academy of Marketing Science, 16 (1), 74-94.

Bagozzi, R.P. and Yi, Y., 1989. On the Use of Structural Equation Models in Experimental Designs. Journal of Marketing Research, XXVI, 271-84.

Baltas, 1997. Determinants of store brand choice: a behavioral analysis. Journal of Product and Brand Management, 6 (5), 315-324.

Bao, Y., Bao, Y. and Sheng, S., 2011. Motivating Purchase of Private Brands: Effects of Store Image, Product Signatureness and Quality Variation. Journal of Business Research, 64 (2), 220-226.

Beristain, J.J., and Zorrilla, P., 2011. The relationship between store image and store brand equity: A conceptual framework and evidence from hypermarkets. Journal of Retailing and Consumer services, 18, 562-574. 
Bigné, E., Borredá, A. and Miquel, M.J., 2013. El valor del establecimiento y su relación con la imagen de marca privada: efecto moderador del conocimiento de la marca privada como oferta propia del establecimiento, Revista Europea de Dirección y Economía de la Empresa, 22, 1-10.

Bigné, E., Vila, N. and Cuenca, A.C., 2001. Conocimiento, preferencia y satisfacción: Interacción en la formación del conjunto de elección de un punto de venta. Esic Market, mayo-agosto, 77-96.

Bloemer, J.M. and Ruyter, K., 1998. On the relationship between store image, store satisfaction and store loyalty. European Journal of Marketing, 32 (5/6), 499-513.

Bollen, K., 1989. Structural Equations with Latent Variables. Villey Series in Probability and Mathematicla Statistic, Ed. John Wiley and Sons, New York.

Brown, J.T. and Dacing, P.A., 1997. The company and the product: corporate associations and con- sumer product responses. Journal of Marketing, 61 (January), 68-84.

Browne, M.W. and Cudeck, R., 1993. Alternative ways of assessing model fit. In A. Bollen and J.S. Long Eds., Testing Structural Equation Models, Sage Publications.

Burke, W. and Schoeffler, S. ,1980. Brand Awareness as a Tool for Profitability. The Strategic Plan- ning Institute, Boston: Cahner Publishing Company, 1980.

Burt, S. and Sparks, L., 2002. Corporate branding, internationalization and the retailer as a brand. Corporate Reputation Review, 5 (2/3), 194-212.

Campbell, D.T. and Fiske, D.W., 1959. Convergent and discriminant validation by multitrait-multi- method matrix. Psychological Bulletin, 56 (2), 81-105.

Caplliure, E.M., Miquel, M.J. and Perez, C., 2009. La elección de la marca del distribuidor en productos duraderos: factores de influencia. Cuadernos de Gestión, 10, 125-147.

Chang, H.H. and Liu, Y.M., 2009. The impact of Brand Equity on Brand Preference and Purchas Intentions in the Service Industries. The Service Industries Journal, 29 (12), 1687.

Chernatony, L., Drury, S. and Segal-Horn, S., 2003. Building a services brand: Stages, people and orientations. The Service Industries Journal, 23 (3), 1- 21.

Chowdhury, J., Reardon, J. and Srivastava, R., 1998. Alternative modes of measuring store image: an empirical assessment of structured versus unstructured measures. Journal of Marketing Theory and Practice, 6 (2), 72-87.

Cobb-Walgren, C., Ruble, C. and Donthu, N.,1995. Brand Equity, Brand Preference and Purchase Intent. Journal of Advertising, 24 (3), 25-40.

Collins-Dodd, C. and Lindley, T. 2003. Store brands and retail differentiation: the influence of store image and store brand attitude on store own brand perceptions. Journal of Retailing and Consumer Services, 10 (6), 345-352.

Corstjens, M. and Lal, R., 2000. Building store loyalty through store brands. Journal of Marketing Research, 37, 281-291.

Del Río, A.B., Vázquez, R. and Iglesias, V., 2002. El valor de marca: Perspectivas de análisis y criterios de estimación. Cuadernos de Gestión, 1 (2), 87-102.

Devlin, D., Birtwistle, G. and Macedo, N., 2003. Food retail positioning strategy: a meansend chain analysis. British Food Journal, 105 (9), 653-670.

De Wulf, K., Oderkerken-Shröder, G., Goedertier, F. and Van Ossel, G.,2005. Consumer Perceptions of Store Brands versus national Brands. Journal of Consumer Marketing, 22 (4), 223-232. 
Dhar, S.K., Hoch, S.J. and Kumar, N., 2000. Effective category management depends on the role of the category. Journal of Retailing, 77, 165-184.

Diamantopoulos, A. and Siguaw, J., 2006. Formative versus Reflective Indicators in Organizational Measure Development: A comparison and Empirical Illlustration. British Journal of Measure Development, 17 (4), 263-282.

Dick, A., Jain, A. and Richardson, P.,1995. Correlates of Store Brand Proneness: Some empirical observations. The Journal of Product and Brand Management, 4 (4), 8-15.

Dodds, W., Monroe, K. and Grewall, D., 1991. Effects on Price, Brand and Store Information on Buyers' Product Evaluations. Journal of Marketing Research, 28 (August), 307-319.

Dubois, B. and Duquesne, P., 1995. Essentiel pour comprende la valeur des marques: la force de conviction. Revue Française du Marketing, 2, 23-34.

Dursun, I., Tümer, E., Koçak, A. and Sezen, B., 2011. Store brand purchase intention: Effects of risk, quality, familiarity and store brand shelf space. Journal of Global Strategic Management, 10, 113-123.

Erdem, O., Oumlil, A.B. and Tuncalp. S. , 1999. Consumer values and the importance of store attributes. International Journal of Retail and Distribution Management, 27 (4), 137-144.

Erdem, T., Swait, J. and Louviere, J. ,2002. The impact of Brand Credibility on Consumer Price Sensitivity. International Journal of Research in Marketing, 19, pp. 1-19

Estelami, H., Lehmann, D.R. and Holden, A.C., 2001. Macro-Economic Determinants of Consumer Price Knowledge: A Meta-Analysis of Four Decades of Research. International Journal of Research in Marketing, 18 (4), 341-355.

Farquhar, P., 1989. Managing Brand Equity. Marketing Research, 48, 24-33.

Faircloth, J.B., Capella, L.M., and Alford, B.L., 2001. The effect of brand attitude and brand image on Brand Equity. Journal of Marketing Theory and Practice, 9 (3), 61-75.

Floor, K., 2006. Branding a store: How to build successful retail brands in a changing marketplace. Ed. Kogan Page, London.

Fornell, C. and Larcker, D., 1981. Evaluating structural equation models with unobservable variables and measurement error. Journal of Marketing Research, 18, 30-50.

García de los Salmones, M., Herrero, A. and Rodríguez del Bosque, I., 2005. Influence of Corporate Social Responsibility on Loyalty and Valuation of Services. Journal of Business Ethics, 61, 369-385.

Grewal, D., Baker, J. Levy, M. and Voss, G.B.,2003. The Effects of Wait Expectations and store atmosphere evaluations on Patronage Intentions in service-intensive Retail stores. Journal of Retailing, 79 (4), 259-268.

Hair, J.F., Anderson, R.E., Tatham, R.L. and Black, W.C.,1992. Multivariable Data Analysis. Mac-Millan Press, London.

Hair, J.F., Anderson, R.E., Tatham, R.L. y Black, W.C ,1999. Analisis Multivariante. Madrid, Prentice Hall

Handelman, J. and Arnold. S., 1999. The role of marketing actions with a social dimension: appeals to the institutional environment. Journal of Marketing, 63 (3), 33-48.

Hoch, S.J. and Banerji, S.,1993. When do Private Labels succeed?. Sloan Management Review, 34 (summer), 57-67.

Huang, Y. and Huddleston, P., 2009. Retailer premium own-brands: creating customer loyalty through own-brand products advantage. International Journal of Retail and Distribution Management, 37 (11), 975-992. 
Juhl, H.J., Esbjerg;L. Grunert, K.G., Bechlarsen, T. and Brunso, K., 2006. The fight between store brands and national brands, What's the score?. Journal of Retailing and Consumer Services, 13 (5), 331-338.

Kapferer, J.N., 2008. The new strategic brand management: creating and sustaining Brand Equity long term. Kogan Page, London.

Keller, K.L., 1993. Conceptualizing, Measuring and Managing Customer-Based Brand Equity. Journal of Marketing, 57 (1), 1-22.

Keller, K.L., 2003. Strategic Brand Management: Building, Measuring and Managing Brand Equity. Second Edition, Upper Saddle River, NJ: Prentice Hall.

Kim, E.Y., Knight, D.K. and Pelton, L.E.,2009. Modeling Brand Equity of a U.S. Apparel Brand as Perceived by Generation Y Consumers in the Emerging Korean Market. Clothing and Textiles Research Journal, 27 (4), 247-258.

Kotler, P. and Armstrong, G., 2008. Principios de marketing. Ed. Pearson, Madrid.

Jara, M. and Cliquet, G.,2012. Retail brand Equity: Conceptualization and measurement. Journal of Retailing and Consumer Services, 19, 140-149.

Jin, B. and Kim, J., 2003. A typology of Korean discount shoppers: Shopping motives, store attributes and outcomes. International Journal of Service Industry Management, 44 (4), 396-419.

Jung, J. and Sung, E-Y., 2008. Consumer-Based Brand Equity: Comparison among Americans and South Koreans in the USA and South Koreans in Korea. Journal of Fashion Marketing and Management, 12 (1), 24-35.

Lassar, W., Mittal, B. and Sharma, A., 1995. Measuring Customer-based Brand Equity. Journal of Consumer Marketing, 12 (4), 11-19.

Lèvy-Mangin, J., 2001. Modelizaciòn y Programaciòn structural con Amos. Editorial Erica, Madrid.

Myers, C.A.,2003. Managing Brand Equity: a look at the impact of attributes. Journal of Product and Brand Management, 12 (1), 39-51.

Nedungadi, P., 1990. Recall and consumer consideration sets: influencing choice without altering brand evaluations. Journal of Consumer Research, 17 (3), 263 276.

Netemeyer, R., Krishnan, B., Pullig, C., Wang, G., Yaggi, M., Dean, D., Ricks, J. and Wirth, F. ,2004. Developing and Validating Measures of Facets of Customer-Based Brand Equity. Journal of Business Research, 57, pp. 209-224.

Pappu, R., Quester, P.G. and Cooksey, R.W., 2005. Consumer-based Brand Equity: improving the measurement-empirical evidence. Journal of Product and Brand Management, 14 (3), 143-154

Pappu, R. and Quester, P.G., 2006. Does customer satisfaction lead to improved Brand Equity: An empirical examination of two categories of retail brands. Journal of Product and Brand Management, 15 (1), 4-14.

Porter, S.S. and Claycomb, C., 1997. The influence of Brand recognition on retail store image. Journal of Product and Brand Management, 6 (6), 373- 387.

Qiu, H.Z.,2003. Structural Equation Modeling: Principles and Practice of Structural Equation Modeling with LISREL. Shuang Yeh Publications, Taipei.

Ragaswamy, A., Burke, R. and Oliva, T. ,1993. Brand Equity and the Extendibility of Brand Names. International Journal of Research in Marketing, 10 (3), 61-75. 
Raju, N. S., van Der Linden, W. J., and Fleer, P. F., 1995. An IRT based internal measure of test bias with applications for differential item functioning. Applied Psychological Measurement, 19, 353-368.

Richardson, P., Jain, A.K. and Dick, A.S., 1994. Extrinsic and Intrinsic Cue Effects on Perceptions of Store Brand Quality. Journal of Marketing, 58, 28-36.

Richardson, P., Jain, A.K. and Dick, A.S. ,1996. Household store brand proneness: A framework. Journal of Retailing, 72 (2), 159 - 185.

Rossiter, J.R. and Percy, L.,1987. Advertising and Promotion Management. New York, NY: Mc- Graw-Hill.

Sayman, S. and Raju, J.S. ,2004. Investigating the Cross-Category Effects of Store Brands. Review of Industrial Organization, 24 (2), 129-141.

Semeijn, J., Van Riel, A. and Ambrosini, A., 2004. Consumer evaluation of Store Brands: Effects of Store image and product attributes. Journal of Retailing and Consumer Services, 11 (4), 247-258.

Sethuraman, R., 2000. What makes Consumers Pay More for National Brands than for Private Labels: Image of Quality?. Marketing Science Institute Paper Series, 00, 110.

Shoell, W.F. and Guiltinan, J.P., 1990. Marketing Contemporary Concepts and Practices. Allyn \& Bacon, Boston, MA.

Sinha, I. and Batra, R., 1999.The effect of consumer price consciousness on private label purchase. International Journal of Research in Marketing, 16 (3), 237-251.

Soberman, D.A. and Parker, P.M., 2006. The economics of quality-equivalent store brands. International Journal of Research in Marketing, 23 (2), 125-139.

Sprott, D.E. and Shimp, T.A., 2004. Using Product Sampling to Augment the Perceived Quality of Store Brands. Journal of Retailing, 80 (4), 305-315.

Steenkamp, J-B. and Dekimpe, M., 1997. The Increasing Power of Private Labels: Building Loyalty and Market Share. Long Range Planning, 30 (6), 917-930.

Steenkamp, E.M. and Van Trijp, C.M.,1991. The Use of LISREL in Validating Marketing Constructs. International Journal of Research in Marketing, 8 (4), 283-299.

Sudhir, K. and Talukdar, D., 2004. Does store brand patronage improve store patronage? Review of Industrial Organization, 24, 143-160.

Swoboda, B., Berg, B., Scharmm-Klein, H. and Foscht, T. 2013. The importance of retail brand equity and store accessibility for store loyalty in local competition. Journal of Retailing and Consumer Services, 20, 251-262.

Thompson, K.E. and Chen, Y.L., 1998. Retail store image: a means-end approach. Journal of Marketing Practice: Applied Marketing Science, 4 (6), 161-173

Turban, D.B. and Greening, D.W., 1996. Corporate Social Performance and organizational attractiveness to prospective employees. Academy of Management Journal, 40, 658672.

Vahie, A. and Paswan, A., 2006. Private label brand image: its relationship with store image and national brand. International Journal of Retail and Distribution Management, 34 (1), 67-84.

Wallace, D.W., Giese, J.L. and Johnson, L., 2004. Customer retailer loyalty in the context of multiplechannel strategies. Journal of Retailing, 80, 249-63.

Wilson, C., 1981. A procedure for the Analysis of Consumer Decision Making. Journal of Advertising Research, 21( 2), 31-38. 
Wu, W. and Lin, Q.H., 2000. Business Research Method. Hwa-Tai Publications, Taipei.

Yoo, B. and Donthu, N.,2001. Developing and Validating a Multidimensional Consumer-based Brand Equity Scale. Journal of Business Research, 52, 1-14.

Yoo, B. and Donthu, N., 2002. Testing Cross-Cultural Invariance of Brand Equity Creation Process. Journal of Product and Brand Management, 11 (6), 195-211.

Zeithaml, V.A., 1988. Consumer Perceptions of Price, Quality and Value: A Means-end Model and Synthesis of Evidence. Journal of Marketing, 52 ( 3), 2-22.

Zeithaml, V.A., Berry, L. and Parasuraman, A., 1996. The behavioral consequences of service qua- lity. Journal of Marketing, 60, 31-46. 
